University of South Florida

DIGITAL COMMONS

Digital Commons @ University of

@ UNIVERSITY OF SOUTH FLORIDA

South Florida

\title{
Photochemical Efficiencies in Reef-Dwelling Anthozoans: Insights from "Survivor" Species
}

\author{
Natasha Mendez-Ferrer \\ University of South Florida, nmendezf@mail.usf.edu \\ Pamela Hallock \\ University of South Florida, pmuller@usf.edu
}

Follow this and additional works at: https://digitalcommons.usf.edu/msc_facpub

Part of the Life Sciences Commons

\section{Scholar Commons Citation}

Mendez-Ferrer, Natasha and Hallock, Pamela, "Photochemical Efficiencies in Reef-Dwelling Anthozoans: Insights from "Survivor" Species" (2019). Marine Science Faculty Publications. 1245.

https://digitalcommons.usf.edu/msc_facpub/1245

This Article is brought to you for free and open access by the College of Marine Science at Digital Commons @ University of South Florida. It has been accepted for inclusion in Marine Science Faculty Publications by an authorized administrator of Digital Commons @ University of South Florida. For more information, please contact digitalcommons@usf.edu. 


\title{
Photochemical Efficiencies in Reef-Dwelling Anthozoans: Insights from "Survivor" Species
}

\author{
Natasha Mendez-Ferrer*, Pamela Hallock \\ College of Marine Science, University of South Florida, 140 7th Ave S, St. Petersburg, FL 33701, USA
}

\begin{abstract}
In recent decades, populations of many coral species have declined dramatically on reefs worldwide. A major factor in coral mortality has been photo-oxidative stress associated with both solar irradiance and elevated temperatures. While many studies have focused on species that have declined, fewer efforts have focused on the "survivor" species, those that have maintained relatively stable populations or even increased in abundance. The objective of this study was to assess temporal variability in photochemical efficiencies $\left(\mathrm{F}_{/} / \mathrm{F}_{\mathrm{m}}\right)$ as an indicator of potential photo-oxidative stress in the dinoflagellate symbionts in three species, the scleractinians Siderastrea siderea and Montastraea cavernosa, and the zoanthid Palythoa caribaeorum, whose populations have remained relatively stable along the Florida reef tract.

Coral colonies with no visual indication of disease or bleaching were assessed quarterly in 2012 and 2013, at sites at 6 or $18 \mathrm{~m}$ depths. Colonies were dark-acclimated prior to measurements using pulse-amplitude modulated fluorometry. The mean $\mathrm{F} / \mathrm{F}_{\mathrm{m}}$ values for $P$. caribaeorum colonies assessed at $6 \mathrm{~m}$ depth were consistently the lowest $(0.59,0.02 \mathrm{SE})$. Siderastrea siderea assessed at both 6 and $18 \mathrm{~m}$ revealed significantly lower $F / F_{m}$ values $(p=0.0006)$ for those living at $6 \mathrm{~m}(0.64,0.02 \mathrm{SE})$ than for those living at $18 \mathrm{~m}(0.68,0.01 \mathrm{SE})$ depths. The $\mathrm{F} / \mathrm{F}_{\mathrm{m}}$ values for colonies of M. cavernosa assessed at $18 \mathrm{~m}$ also averaged 0.68 (0.01 SE). Thus, photochemical efficiencies were lower in colonies living at $6 \mathrm{~m}$ than in colonies living at $18 \mathrm{~m}$, while no significant seasonal differences were found in the mean $\mathrm{F}_{\sqrt{ }} / \mathrm{F}_{\mathrm{m}}$ values in the examined species. This study provides the first known report of photochemical efficiency in P. caribaeorum.
\end{abstract}

Keywords: Photo-oxidative stress; Dinoflagellate symbionts; Photosynthetic organisms

\section{INTRODUCTION}

The loss in total coral cover and potential for reef accretion in recent decades has been observed nearly worldwide, and especially throughout the western Atlantic and Caribbean. With losses in coral cover after the 1997-98 El Niño bleaching event and the 2010 cold-water mortality event that devastated Orbicella populations, Montastraea cavernosa Linnaeus 1766 and Siderastrea siderea Ellis and Solander 1786 are now among the greatest contributors to total stony coral cover on the Florida reef tract [1]. Although reefs in the Florida Keys seem to be in a transition from hard-coral to octocoral domination, coral-population studies on this region show that benthic cover by M. cavernosa, S. siderea, and the common zoanthid, Palythoa caribaeorum Duchassaing and Michelotti 1860, has remained relatively stable $[1,2]$. With populations of the major reef-building species in rapid decline, research has tended to focus on the formerly dominant species of Acropora and Orbicella $[3,4]$. In this study, we focus instead upon three "survivor" taxa, $\mathrm{M}$. cavernosa, S. siderea and P. caribaeorum, by assessing photochemical efficiencies in situ at two depths along the Florida reef tract.

Photosynthesis by symbiotic dinoflagellates (commonly known as zooxanthellae) provides corals with energy needed for metabolism, growth and reef building [5,6]. The taxonomic status of the zooxanthellae has recently been revised, with the establishment of the Family Symbiodiniaceae and assignment of generic names to clades [7]. Cunning et al. [8] found clades C (genus Cladocopium) and D1a (genus Durusdinium) in both M. cavernosa and S. siderea, while Kemp et al. [9] reported subclades C1 and D1a in P. caribaeorum. This zoanthid is abundant in shallow forereefs around the Caribbean, as well as those of both the North and South Atlantic [9-11]. Colonies of P. caribaeorum also are susceptible to bleaching under thermal and irradiance stresses [12].

The photosynthetic capacity of the symbionts can be affected by an array of environmental stressors, with solar irradiance and thermal stress being the most studied, as these can induce

Correspondence to: Mendez-Ferrer N, Gulf of Mexico Fishery Management Council, 4107 West Spruce St, suite 200, Tampa, FL 33607, USA, Tel. (813) 348-1630x228; E-mail: Natasha.Mendez@gulfcouncil.org

Received: April 17, 2019; Accepted: May 28, 2019; Published: June 04, 2019

Citation: Mendez-Ferrer N, Hallock P (2019) Photochemical Efficiencies in Reef-Dwelling Anthozoans: Insights from "Survivor" Species. J Oceanogr Mar Res 7:193. doi: 10.24105/2572-3103.1000193

Copyright: (C) 2019 Mendez-Ferrer N, et al. This is an open-access article distributed under the terms of the Creative Commons Attribution License, which permits unrestricted use, distribution, and reproduction in any medium, provided the original author and source are credited. 
bleaching [13,14]. Pulse-amplitude modulated (PAM) fluorometery has become a widely used tool to study stress in photosynthetic organisms by using chlorophyll $a$ fluorescence as proxy to assess the photochemical efficiency of photosystem II (PSII) of the symbiont [15]. Thermal and photic damage to PSII has been linked to symbiont loss in corals $[16,17]$ and such damage can create a cascade of events resulting in an overall decrease in productivity of the symbiont and thus in less photosynthate available for the coral host [12].

Results from PAM fluorometry can provide insight into the photosynthetic capacity of PSII by measuring the ratio of variable fluorescence to maximum fluorescence $\left(\mathrm{F}_{\sqrt{ }} / \mathrm{F}_{\mathrm{m}}=\right.$ maximum quantum yield of PSII). For example, declines in $F / F_{m}$ have been reported in corals with indications of bleaching, during diel fluctuations that correlate with the diurnal cycle of solar irradiance, and with seasonal changes in temperature and light [18-21].

The purpose of this study was to assess temporal variability in photochemical efficiencies of the symbionts in three "survivor" taxa. We examined how in situ maximum quantum yields of photosystem II of the anthozoans, M. cavernosa, S. siderea and P. caribaeorum, varied through the year and, for S. siderea, between 6 and $18 \mathrm{~m}$ depths. The working hypothesis was that photochemical efficiencies would change over the course of a year as irradiance and water temperature changed with seasons. Our results provide insight into why populations of these anthozoans in the Florida Keys have remained relatively stable over the past few decades.

\section{METHODS}

Water temperature and solar irradiance data spanning the period of fieldwork were acquired from satellite-derived sources. Monthly means of sea-surface temperature data for 2012-13 were obtained from NOAA's Advanced Very High Resolution Radiometer (AVHRR) at $1 \mathrm{~km}^{2}$ resolution. Data for ultraviolet (UVA, $380 \mathrm{~nm}$ ) and visible (blue light, $480 \mathrm{~nm}$ ) penetrating to 6 and $18 \mathrm{~m}$ depth were calculated using protocols established by Barnes et al. for Florida reef tract waters [22-24].

In situ fluorescence measurements were undertaken quarterly, as close as logistics permitted to the solstices and equinoxes, between June 2012 and October 2013, at Tennessee Reef on the Florida reef tract (Figure 1). Two sites were selected along this reef: a $6 \mathrm{~m}$ site $\left(24.7453^{\circ},-80.7818^{\circ}\right)$ and an $18 \mathrm{~m}$ site $\left(24.7523^{\circ},-80.7549^{\circ}\right)$. Colonies of Sidestrea siderea and Palythoa caribaeorum were assessed at the $6 \mathrm{~m}$ site, while S. siderea and Monstastraea cavernosa were assessed at the $18 \mathrm{~m}$ site.

Each sampling event consisted of selecting three colonies of each species at each site. The colonies assessed during each sampling event were not always the same. Specimens selected for study exhibited healthy coloration and no visible signs of disease or bleaching. The colonies were dark-acclimated for at least 20 minutes by covering them under large, black plastic bags; those at $18 \mathrm{~m}$ were covered during an initial SCUBA dive and assessed during a subsequent dive, following an appropriate surface interval. The fluorescence measurements where taken while keeping the colonies shaded, therefore measurements (three per colony) were taken "blindly" across each colony to avoid intrusion of outside sunlight. A Walz DIVING PAM fluorometer was used to measure the parameters $\mathrm{F}_{0}$ (fluorescence after dark-acclimation) and $\mathrm{F}_{\mathrm{m}}$ (fluorescence after

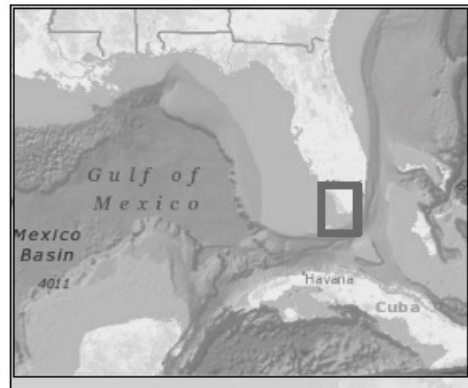

\section{Site}

$$
\begin{aligned}
& \star \quad 6 \mathrm{~m} \\
& \star \quad 18 \mathrm{~m}
\end{aligned}
$$

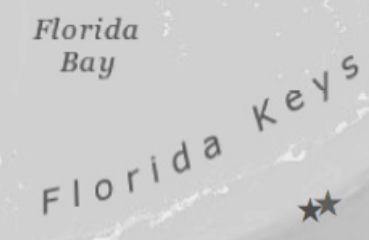

Figure 1: Locations of the Tennessee Reef field sites on the Florida reef tract, USA; inset shows the general location relative to the Gulf of Mexico.

a saturating flash of light). These measurements were then used to derive the mean maximum quantum yield of photosystem II $\left[F_{\checkmark}\right]$ $\left.\mathrm{F}_{\mathrm{m}}=\left(\mathrm{F}_{\mathrm{m}}-\mathrm{F}_{\mathrm{o}}\right) / \mathrm{F}_{\mathrm{m}}\right]$ for each colony.

A non-parametric approach was used to test the null hypotheses of: a) no significant difference in $F_{f} / F_{m}$ within species among sampling dates, and b) no significant difference in $F / F_{m}$ between colonies of S. siderea at $6 \mathrm{~m}$ and $18 \mathrm{~m}$. Permutation-based analysis of variance (NP-ANOVA) was carried out using the Fathom Toolbox for MATLAB [25,26].

\section{RESULTS}

Monthly means of sea-surface temperature and selected wavelengths of solar irradiance (380 and $488 \mathrm{~nm}$ ) reaching the seafloor at Tennessee Reef for the years 2012 and 2013 [27] are shown in Figure 2. Average winter lows of $\sim 25^{\circ} \mathrm{C}$ occurred in January each year, while summer highs averaging just under $30^{\circ} \mathrm{C}$ occurred each September (Figure 2A). Visible solar radiation reaching the seafloor at $6 \mathrm{~m}$ revealed a typical seasonal cycle, with winter lows (December-January) and summer highs in June (Figure 2B). Visible light reaching the seafloor at $18 \mathrm{~m}$ was more variable. Similarly, mean UVA radiation reaching the seafloor also varied, exhibiting not only winter lows but also July-August lows in 2012 and MayJune lows in 2013 (Figure 2C).

In situ data for maximum quantum yields for all taxa revealed $\mathrm{F}_{\sqrt{ }} / \mathrm{F}_{\mathrm{m}}$ values in the range of $0.37-0.78$. Based on dispersion analysis, the variability in $\mathrm{F} / \mathrm{F}_{\mathrm{m}}$ among the species did not differ significantly $(\mathrm{p}=0.08)$. The mean $\mathrm{F} / \mathrm{F}_{\mathrm{m}}$ values for Palythoa caribaeorum (0.59, 


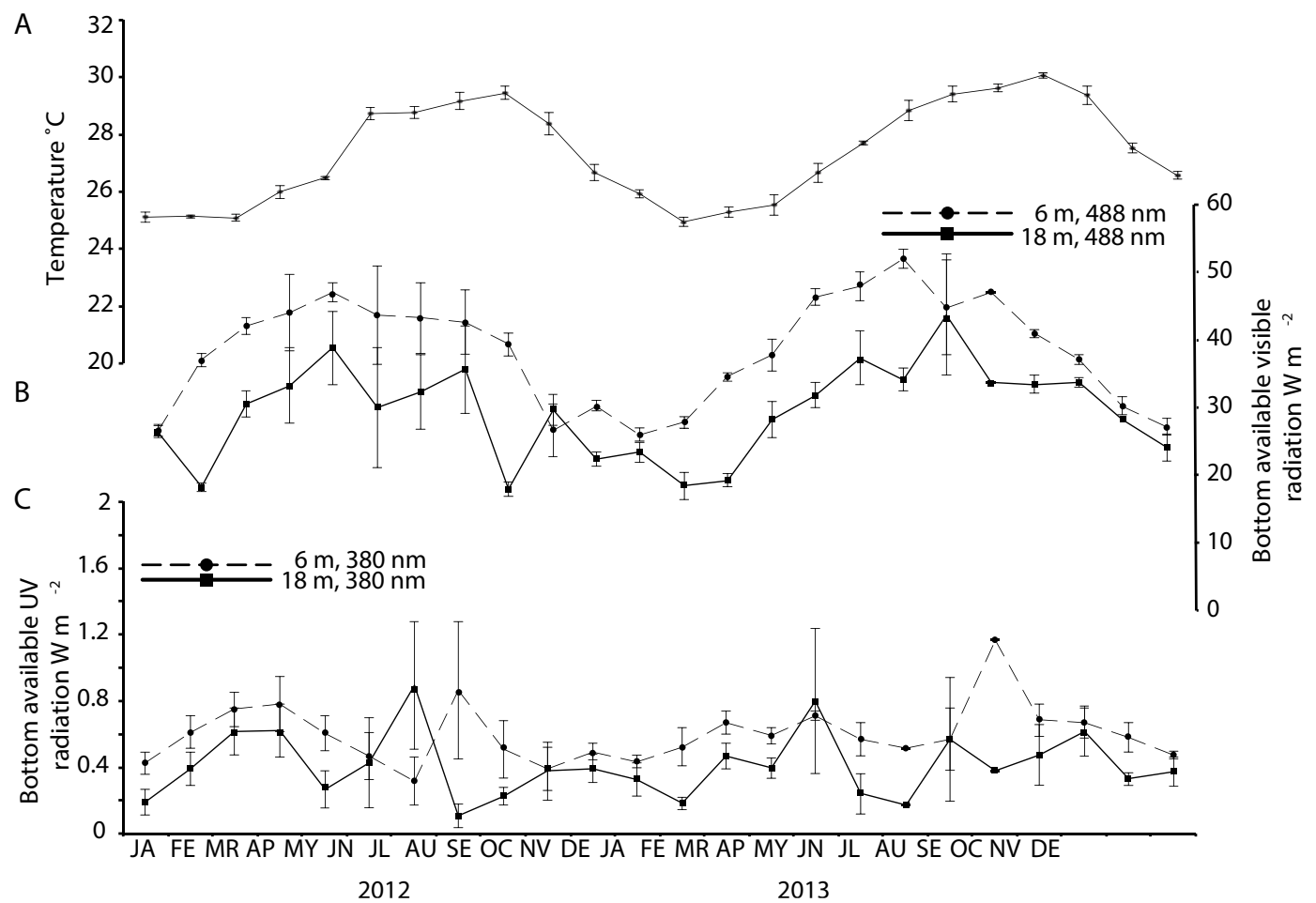

Figure 2: Monthly means ( \pm SE) of sea-surface temperature and bottom-available irradiance for the years 2012 and 2013 [27]. A SST at Tennessee Reef, 6 $\mathrm{m}$ site. B Bottom-available blue irradiance $(488 \mathrm{~nm})$ at $6 \mathrm{~m}$ and $18 \mathrm{~m}$. C Bottom-available UVA irradiance $(380 \mathrm{~nm})$ at $6 \mathrm{~m}$ and $18 \mathrm{~m}$.
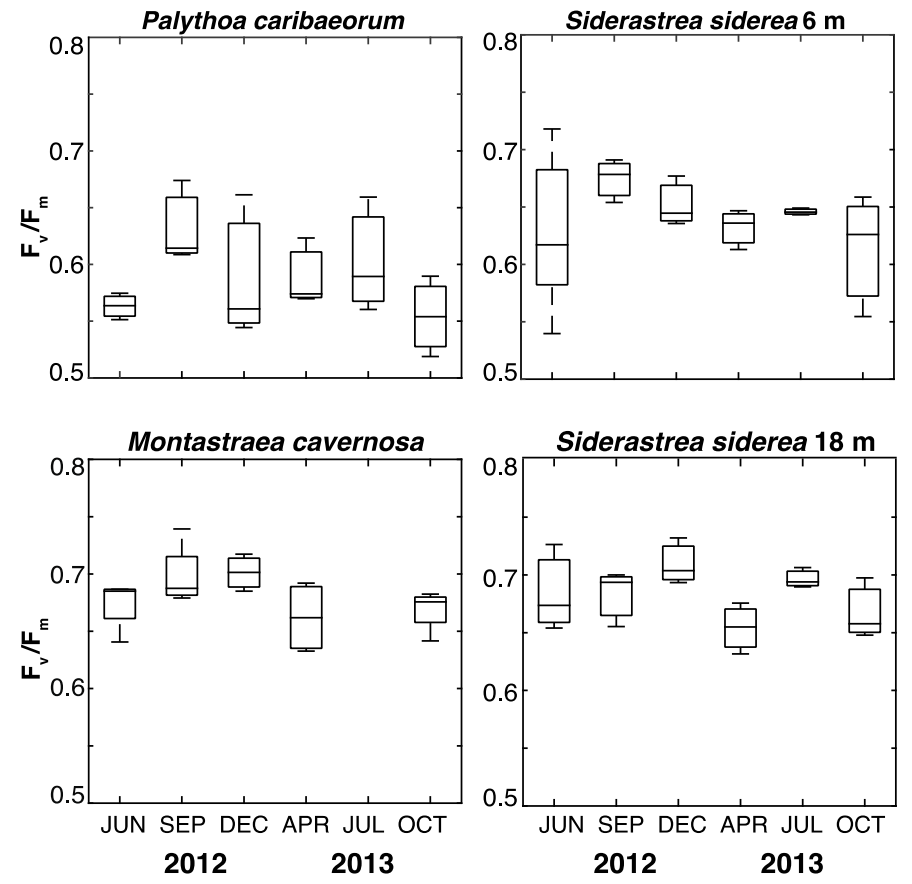

Figure 3: Boxplot of the maximum quantum yields for Palythoa caribaeorum and Siderastrea siderea at $6 \mathrm{~m}$ depth, Montastraea cavernosa and S. siderea at 18 $\mathrm{m}$ depth. No data were recorded for M. cavernosa for July 2013.

$0.02 \mathrm{SE}$ ) were consistently the lowest (Figure 3), with no significant differences discerned over time (Table 1). The $F / F_{m}$ values for Siderastrea siderea at neither the $6 \mathrm{~m}$ site $(0.64,0.02 \mathrm{SE})$ nor the 18 $\mathrm{m}$ site $(0.68 ; 0.01 \mathrm{SE})$ differed significantly across sampling dates (Figure 3). The mean $F / F_{m}$ values for colonies of $S$. siderea at $6 \mathrm{~m}$ were significantly lower than for those living at $18 \mathrm{~m}$ depth (Table 2). In colonies of $M$. cavernosa, no significant differences in $F / F_{m}$ were seen over the course of the study $(0.68 ; 0.01 \mathrm{SE}$; Table 1$)$. Due to logistical issues, data from M. cavernosa colonies were not collected in July 2013.

\section{DISCUSSION}

Considering the relatively strong seasonality in both temperature and solar irradiance experienced by corals living along the Florida reef tract, we anticipated finding seasonal changes for in situ maximum quantum yields in the taxa assessed. Warner et al, examining colonies of three species of Orbicella from the Bahamas, found the greatest fluctuations in $\mathrm{F} / \mathrm{F}_{\mathrm{m}}$ from corals in very shallow waters (1-2 m), whereas those from somewhat deeper waters (3-4 $\mathrm{m}$ and $14 \mathrm{~m})$ produced consistently higher and less variable $\mathrm{F}_{\sqrt{ }}$ $\mathrm{F}_{\mathrm{m}}$ values [20]. These fluctuations in $\mathrm{F} / \mathrm{F}_{\mathrm{m}}$ were strongly correlated 
Table 1: One-way NP-ANOVA on the maximum quantum yield between sampling months for the zoanthid Palythoa caribaeorum, Siderastrea siderea at 6 and $18 \mathrm{~m}$ depths, and Montastraea cavernosa at $18 \mathrm{~m}$ depth. In each comparison, 5,000 permutations were run; $\alpha=0.05$.

\begin{tabular}{|c|c|c|c|c|c|c|c|c|c|c|}
\hline \multirow{2}{*}{$\begin{array}{c}\text { Species } \\
\text { Depth }\end{array}$} & \multicolumn{5}{|c|}{ Palythoa caribaeorum } & \multicolumn{5}{|c|}{ Siderastrea siderea } \\
\hline & & & $6 \mathrm{~m}$ & & & & & $6 \mathrm{~m}$ & & \\
\hline Factor & Mean Fv/Fm & SE & df & $\mathrm{F}$ & $\mathrm{p}$ & Mean Fv/Fm & SE & df & $\mathrm{F}$ & $\mathrm{p}$ \\
\hline Overall & 0.59 & 0.02 & & & & 0.64 & 0.02 & & & \\
\hline Month & & & 5 & 1.4 & 0.28 & & & 5 & 0.75 & 0.59 \\
\hline Residual & & & 12 & & & & & 14 & & \\
\hline Total & & & 17 & & & & & 19 & & \\
\hline & & & & & & & & & & \\
\hline Species & \multicolumn{5}{|c|}{ Montastraea cavernosa } & \multicolumn{5}{|c|}{ Siderastrea siderea } \\
\hline Depth & & & $18 \mathrm{~m}$ & & & & & $18 \mathrm{~m}$ & & \\
\hline Factor & Mean Fv/Fm & SE & df & $\mathrm{F}$ & $\mathrm{p}$ & Mean Fv/Fm & SE & $\mathrm{df}$ & $\mathrm{F}$ & $\mathrm{p}$ \\
\hline Overall & 0.68 & 0.01 & & & & 0.68 & 0.01 & & & \\
\hline Month & & & 4 & 2.41 & 0.09 & & & 5 & 1.95 & 0.17 \\
\hline Residual & & & 16 & & & & & 12 & & \\
\hline Total & & & 20 & & & & & 17 & & \\
\hline
\end{tabular}

Table 2: Two-way NP-ANOVA on the photochemical efficiency between $6 \mathrm{~m}$ and $18 \mathrm{~m}$ for colonies of Siderastrea siderea; 5,000 permutations; $\alpha=$ 0.05 .

\begin{tabular}{|c|c|c|c|}
\hline Factor & df & F & p \\
\hline Depth & 1 & 13.31 & 0.0006 \\
\hline Residual & 36 & & \\
\hline Total & 37 & & \\
\hline
\end{tabular}

to seasonal patterns of water temperature and irradiance, with lower $\mathrm{F} / \mathrm{F}_{\mathrm{m}}$ consistently recorded during the summer months [20]. Significant reduction in densities of zooxanthellae in P. caribaeorum from Brazil was recorded during summer months [27,28]. In addition, photosynthesis and respiration studies on Orbicella (né Montastraea) faveolata colonies from the Florida Keys have also shown lower gross photosynthesis during the summer months [29].

The expected seasonal patterns of lower $F / F_{m}$ during warmer months and higher during colder months were not observed in our study, consistent with those from sites $>2 \mathrm{~m}$ [20], as noted above. Moreover, although we worked at the same sites each time, the colonies assessed where not always the same. Site depth, inherent variability among colonies, small sample sizes, and relatively mild winter and summer temperatures during our study could be reasons why seasonal trends were not readily evident.

On the other hand, given that fluctuations in $\mathrm{F} / \mathrm{F}_{\mathrm{m}}$ were quite minimal over time in all three species, these responses indicate that these species are well adapted to seasonal changes in temperature and irradiance, at least to those experienced during 2012-13. Moreover, the differences in $\mathrm{F}_{\sqrt{ }} / \mathrm{F}_{\mathrm{m}}$ values between the $6 \mathrm{~m}(0.64$ for S. siderea $)$ and $18 \mathrm{~m}$ (0.68 for S. siderea and M. cavernosa $)$ data are notably similar to with those reported by Lesser et al [30], for M. cavernosa from similar depths in the Bahamas.

The moderate temperature ranges recorded in 2012-13 likely played a role in the minimal fluctuations in $\mathrm{F} / \mathrm{F}_{\mathrm{m}}$ over the duration of our study. These temperature ranges are normal for the Keys reef tract and summer temperatures did not reach levels known to induce bleaching. The normal visible light cycle in which the highest light levels at $6 \mathrm{~m}$ depth were recorded in June, well before the September temperature peak, limited the interaction of high light compounding stress induced by elevated temperatures. Solar radiation reaching the seafloor at $18 \mathrm{~m}$ can be much more J Oceanogr Mar Res, Vol. 7 Iss. 2 No: 193 ISSN: 2572-3103 dependent upon water transparency, which can be influenced by plankton blooms, outflow of turbid water from Florida Bay, or frequency of storms [31].

This paper reports the first known assessment of photosynthetic efficiencies of the zoanthid Palythoa caribaeorum. This common species is widely studied for its production of palytoxin and other potential biochemicals of medical interest, but much less is known regarding its responses to photic stress [32]. Kemp et al. reported results of experiments on thermal tolerance, noting that this species in south Florida harbored two genetic types of zooxanthellae (C1 and D1a), though thermal tolerance did not seem to be influenced by the clade of zooxanthellae present in the host [9].

In situ analyses of photochemical efficiencies across seasons cannot provide a full picture of the photosynthetic performance of a symbiotic organism. Nevertheless, such analyses can contribute to understanding how anthozoan "survivor" species and their symbionts cope with environmental extremes. Future studies of symbiont heterogeneity, including during recovery from bleaching, predation or disease, in combination with in situ assessments of photochemical efficiencies, are needed to enhance understanding of how benthic zooxanthellate anthozoans respond to and recover from photo-oxidative stress.

\section{ACKNOWLEDGMENTS}

Field work in Tennessee Reef, Florida reef tract, was carried out under the Florida Keys National Marine Sanctuary permit number FKNMS-2011-01. Fieldwork was supported in part by the Cushman Foundation for Foraminiferal Research and SRI International. The Wal $z^{\circledR}$ PAM fluorometer was purchased under the BP/Gulf of Mexico Research Initiative through the Florida Institute of Oceanography. We also thank the staff of the Keys Marine Laboratory for logistical support, and volunteer divers from the College of Marine Science at the University of South Florida who participated in the study: Andrea Schmidt, Benjamin Ross, Brian Barnes, Joshua Kilborn, María Vega-Rodríguez, and Tiffany Boisvert. Special thanks to the NSF FG-LSAMP Bridge to the Doctorate award (HRD \#0929435), the Alfred P. Sloan Minority $\mathrm{PhD}$ program, the USF Mayor's Advisory Council Fellowship, and the Johanna M. Resig Fellowship from the Cushman Foundation, for financial support of N. Méndez-Ferrer. 


\section{REFERENCES}

1. Ruzicka R, Colella M, Semon K, Brinkhuis V, Morrison J, Kidney J, et al. CREMP 2009 Final Report. Fish \& Wildlife Research Institute/Florida Fish \& Wildlife Conservation Commission, Saint Petersburg, FL, 2010.

2. Ruzicka RR, Colella MA, Porter JW, Morrison JM, Kidney JA, Brinkhuis $\mathrm{V}$, et al. Temporal changes in benthic assemblages on Florida Keys reefs 11 years after the 1997/1998 El Niño. Mar Ecol-Prog Ser. 2013;489:125-141.

3. Kimes NE, Johnson WR, Torralba M, Nelson KE, Weil E, Morris PJ. The Montastraea faveolata microbiome: ecological and temporal influences on a Caribbean reef-building coral in decline. Environ Microbiol. 2013;15(7):2082-2094.

4. Enochs IC, Manzello DP, Carlton R, Schopmeyer S, Hooidonk $\mathrm{R}$, Lirman D. Effects of light and elevated $\mathrm{pCO} 2$ on the growth and photochemical efficiency of Acropora cervicornis. Coral Reefs. 2014;33:477-485.

5. Muscatine L, Porter JW. Reef corals: mutualistic symbioses adapted to nutrient-poor environments. BioScience. 1977;27(7):454-460.

6. Barnes DJ, Chalker BE. Calcification and photosynthesis in reef-building corals and algae. In: Dubinsky Z (ed.) Ecosystems of the world: 25 Coral reefs. Elsevier Science Publishing Company, Amsterdam, 1990;109-131.

7. LaJeunesse TC, Parkinson JE, Gabrielson PW, Jeong HJ, Reimer JD, Voolstra CR, et al. (2018) Systematic revision of Symbiodiniaceae highlights the antiquity and diversity of coral endosymbionts. Curr Biol. 2018;28(16):2570-2580.

8. Cunning R, Silverstein RN, Baker AC (2018) Symbiont shuffling linked to differential photochemical dynamics of Symbiodinium in three Caribbean reef corals. Coral Reefs. 2018;37(1):145-152.

9. Kemp DW, Cook CB, LaJeunesse TC, Brooks WR. A comparison of the thermal bleaching responses of the zoanthid Palythoa caribaeorum from three geographically different regions in south Florida. J Exp Mar Biol Ecol. 2006;335(2):266-276.

10. Rabelo EF, Rocha LL, Colares GB, Bomfim TA, Nogueira VLR, Katzenberger M, et al. Symbiodinium diversity associated with zoanthids (Cnidaria: Hexacorallia) in Northeastern Brazil. Symbiosis. 2014;64:105-113.

11. Reimer JD, Lorion J, Irei Y, Hoeksema BW, Wirtz P. Ascension Island shallow water Zoantharia (Hexacorallia: Cnidaria) and their zooxanthellae (Symbiodinium). J Mar Biol Assoc UK. 2017;97(4):695-703.

12. Lesser MP, Stochaj WR, Tapley DW, Shick JM. Bleaching in coral reef anthozoans: effects of irradiance, ultraviolet radiation, and temperature on the activities of protective enzymes against active oxygen. Coral Reefs. 1990;8(4):225-232.

13. Prieto RI, Matta JL, Robins WA, Trench RK. Photosynthetic response to elevated-temperature in the symbiotic dinoflagellate Symbiodinium-microadriaticum in culture. Proc Natl Acad Sci. 1992;89(21):10302-10305.

14. Tchernov D, Gorbunov MY, de Vargas C, Narayan Yadav S, Milligan AJ, Häggblom M, et al. Membrane lipids of symbiotic algae are diagnostic of sensitivity to thermal bleaching in corals. Proc Natl Acad Sci USA. 2004;101(37):13531-13535.

15. Genty B, Briantais JM, Baker NR. The relationship between the quantum yield of photosynthetic electron transport and quenching of chlorophyll fluorescence. BBA-Gen Subjects. 1989;990(1):87-92.

16. Weis VM. Cellular mechanisms of cnidarian bleaching: stress causes the collapse of symbiosis. J Exp Biol. 2008;211(19):3059. 3066.

17. Lesser MP. Coral bleaching: causes and mechanisms. In: Dubinsky Z, Stambler N (eds) Coral Reefs: An Ecosystem in Transition. Springer, Netherlands, 2011;405-419.

18. Brown BE, Ambarsari I, Warner ME, Fitt WK, Dunne RP, Gibb SW, et al. Diurnal changes in photochemical efficiency and xanthophyll concentrations in shallow water reef corals: evidence for photoinhibition and photoprotection. Coral Reefs. 1999;18:99-105.

19. Fitt W, Brown B, Warner M, Dunne R. Coral bleaching: interpretation of thermal tolerance limits and thermal thresholds in tropical corals. Coral Reefs. 2001;20(1):51-65.

20. Warner ME, Chilcoat GC, McFarland FK, Fitt WK. Seasonal fluctuations in the photosynthetic capacity of photosystem II in symbiotic dinoflagellates in the Caribbean reef-building coral Montastraea. Mar Biol. 2002;141(1):31-38.

21. Brown BE, Dunne RP. Solar radiation modulates bleaching and damage protection in a shallow water coral. Mar Ecol-Prog Ser. 2008;362:99-107.

22. Barnes B, Hu C, Schaeffer BA, Lee Z, Palandro DA, et al. MODIS-derived spatiotemporal water clarity patterns in optically shallow Florida Keys waters: A new approach to remove bottom contamination. Remote Sens Environ. 2013;134:377-391.

23. Barnes B, Hu C, Cannizzaro JP, Craig SE, Hallock P, et al. Estimation of diffuse attenuation of ultraviolet light in optically shallow Florida Keys waters from MODIS measurements. Remote Sens Environ. 2014;140:519-532.

24. Barnes B, Hallock P. Hu C, Karger FM, Palandro, et al. Prediction of coral bleaching in the Florida Keys using remotely sensed data. Coral Reefs. 2015;34:491-503.

25. Anderson MJ. A new method for non-parametric multivariate analysis of variance. Austral Ecol. 2001;26:32-46.

26. Jones D. The fathom toolbox for MATLAB: multivariate ecological and oceanographic data analysis. College of Marine Science, University of South Florida, St. Petersburg, FL, USA, 2014.

27. Mendez-Ferrer N, Hallock P, Jones D. Photochemical efficiencies of diatom symbionts in hospite in Amphistegina gibbosa (foraminifera) across seasons in the Florida Keys, USA. J Foramin Res. 2018;48:4-16.

28. Costa CF, Sassi R, Gorlach-Lira K, LaJeunesse TC, Fitt WK. Seasonal changes in zooxanthellae harbored by zoanthids (Cnidaria, Zoanthidea) from coastal reefs in northeastern Brazil. Pan Am J Aquat Sci. 2013;8:253-264.

29. Swart PK, Szmant A, Porter JW, Dodge RE, Tougas JI, et al. The isotopic composition of respired carbon dioxide in 
scleractinian corals: Implications for cycling of organic carbon in corals. Geochim Cosmochim Acta. 2005;69:1495-1509.

30. Lesser MP, Slattery M, Stat M, Ojimi M, Gates RD. Photoacclimatization by the coral Montastraea cavernosa in the mesophotic zone: light, food, and genetics. Ecology. 2010;91:990-1003.
31. Szmant AM, Forrester A. Water column and sediment nitrogen and phosphorous distribution patterns in the Florida Keys, USA. Coral Reefs. 1996;15:21-41.

32. Munday R. Palytoxin toxicology: Animal studies. Toxicon. 2011;57(SI):470-477. 